\title{
Universität Zürich
}

Physiologisches Institut

Vorsteher: Prof. Dr. med. F. Verrey

Arbeit unter der Leitung von Prof. Dr. med. C. A. Wagner

\section{The calcium-sensing receptor acts as a modulator of gastric acid secretion in freshly isolated human gastric glands}

\author{
INAUGURAL-DISSERTATION \\ zur Erlangung der Doktorwürde der Medizinischen Fakultät \\ der Universität Zürich
}

vorgelegt von

Matthias Michael Dufner

von Deutschland

Genehmigt auf Antrag von Prof. Dr. med. C. A. Wagner Zürich 2008 
Die Arbeit wurde vorab veröffentlicht:

Dufner MM, Kirchhoff P, Remy C, Hafner P, Muller MK, Cheng SX, Tang LQ, Herbert SC, Geibel JP, Wagner CA. The calcium-sensing receptor acts as a modulator of gastric acid secretin in freshly isolated human gastric glands. Am J Physiol Gastrointest Liver Physiol. 289: G1084-90, 2005 


\title{
The calcium-sensing receptor acts as a modulator of gastric acid secretion
}

\author{
in freshly isolated human gastric glands
}

\author{
Matthias M. Dufner, ${ }^{1,2, *}$ Philipp Kirchhoff, ${ }^{2, *}$ Christine Remy, ${ }^{1}$ Patricia Hafner, ${ }^{1}$ Markus K. Müller, ${ }^{2}$ \\ Sam X. Cheng, ${ }^{3}$ Lie-Qi Tang, ${ }^{3}$ Steven C. Hebert, ${ }^{3}$ John P. Geibel,,${ }^{3,4}$ and Carsten A. Wagner ${ }^{1}$ \\ ${ }^{1}$ Institute of Physiology and Center for Integrative Human Physiology and ${ }^{2}$ Division of Visceral \\ and Transplant Surgery, University of Zurich, Zurich, Switzerland; and Departments of ${ }^{3}$ Cellular \\ and Molecular Physiology and ${ }^{4}$ Surgery, Yale School of Medicine, New Haven, Connecticut
}

Submitted 29 December 2004; accepted in final form 12 August 2005

Dufner, Matthias M., Philipp Kirchhoff, Christine Remy, Pa-
tricia Hafner, Markus K. Müller, Sam X. Cheng, Lie-Qi Tang, Steven C. Hebert, John P. Geibel, and Carsten A. Wagner. The calcium-sensing receptor acts as a modulator of gastric acid secretion in freshly isolated human gastric glands. Am J Physiol Gastrointest Liver Physiol 289: G1084-G1090, 2005. First published August 18, 2005; doi:10.1152/ajpgi.00571.2004.-Gastric acid secretion is activated by two distinct pathways: a neuronal pathway via the vagus nerve and release of acetylcholine and an endocrine pathway involving gastrin and histamine. Recently, we demonstrated that activation of $\mathrm{H}^{+}-\mathrm{K}^{+}$-ATPase activity in parietal cells in freshly isolated rat gastric glands is modulated by the calcium-sensing receptor (CaSR). Here, we investigated if the CaSR is functionally expressed in freshly isolated gastric glands from human patients undergoing surgery and if the CaSR is influencing histamine-induced activation of $\mathrm{H}^{+}-\mathrm{K}^{+}$ATPase activity. In tissue samples obtained from patients, immunohistochemistry demonstrated the expression in parietal cells of both subunits of gastric $\mathrm{H}^{+}-\mathrm{K}^{+}$-ATPase and the CaSR. Functional experiments using the $\mathrm{pH}$-sensitive dye $2^{\prime}, 7^{\prime}$-bis-(2-carboxyethyl)-5-(and 6)-carboxyfluorescein and measurement of intracellular $\mathrm{pH}$ changes allowed us to estimate the activity of $\mathrm{H}^{+}-\mathrm{K}^{+}$-ATPase in single freshly isolated human gastric glands. Under control conditions, $\mathrm{H}^{+}-\mathrm{K}^{+}-$ ATPase activity was stimulated by histamine $(100 \mu \mathrm{M})$ and inhibited by omeprazole $(100 \mu \mathrm{M})$. Reduction of the extracellular divalent cation concentration $\left(0 \mathrm{Mg}^{2+}, 100 \mu \mathrm{M} \mathrm{Ca}^{2+}\right)$ inactivated the CaSR and reduced histamine-induced activation of $\mathrm{H}^{+}-\mathrm{K}^{+}$-ATPase activity. In contrast, activation of the CaSR with the trivalent cation $\mathrm{Gd}^{3+}$ caused activation of omeprazole-sensitive $\mathrm{H}^{+}-\mathrm{K}^{+}$-ATPase activity even in the absence of histamine and under conditions of low extracellular divalent cations. This stimulation was not due to release of histamine from neighbouring enterochromaffin-like cells as the stimulation persisted in the presence of the $\mathrm{H}_{2}$ receptor antagonist cimetidine $(100 \mu \mathrm{M})$. Furthermore, intracellular calcium measurements with fura- 2 and fluo- 4 showed that activation of the CaSR by $\mathrm{Gd}^{3+}$ led to a sustained increase in intracellular $\mathrm{Ca}^{2+}$ even under conditions of low extracellular divalent cations. These experiments demonstrate the presence of a functional CaSR in the human stomach and show that this receptor may modulate the activity of acid-secreting $\mathrm{H}^{+}-\mathrm{K}^{+}$ATPase in parietal cells. Furthermore, our results show the viability of freshly isolated human gastric glands and may allow the use of this preparation for experiments investigating the physiological regulation and properties of human gastric glands in vitro.

stomach; $\mathrm{H}^{+}-\mathrm{K}^{+}$-ATPase; parietal cells

GASTRIC ACID SECRETION by parietal cells is under the control of both neuronal regulation via the vagus nerve involving the

\footnotetext{
* M. M. Dufner and P. Kirchhoff contributed equally to this work.

Address for reprint requests and other correspondence: C. A. Wagner, Institute of Physiology, Univ. of Zurich, Winterthurerstrasse 190, CH-8057 Zurich, Switzerland (e-mail: Wagnerca@access.unizh.ch).
}

release of acetylcholine and under the control of endocrine and paracrine factors including gastrin and histamine. Histamine is released from neighboring enterochromaffin-like cells (ECL) and triggers an intracellular signaling cascade in parietal cells leading to the insertion of $\mathrm{H}^{+}-\mathrm{K}^{+}$-ATPases from tubulovesicular structures into the luminal membrane, where acid secretion takes place (17). The exposure to histamine also causes a simultaneous rise in intracellular $\mathrm{Ca}^{2+}\left(\mathrm{Ca}_{\mathrm{i}}^{2+}\right)$, which has served as an additional marker for activated acid secretion $(2,4)$.

In addition to these classic pathways regulating gastric acid secretion, the calcium-sensing receptor (CaSR) has been identified in rat gastric parietal cells $(2,10)$. The CaSR is activated by divalent cations, $\mathrm{Ca}^{2+}$ and $\mathrm{Mg}^{2+}$, the trivalent cation $\mathrm{Gd}^{3+}$, and by substrates like spermine. Its sensitivity to these ligands is modulated by L-amino acids and $\mathrm{pH}(5,6,18)$. Activation of $\mathrm{CaSR}$ in rat parietal cells induced an increase in $\mathrm{Ca}_{\mathrm{i}}^{2+}$ concentrations $\left(\left[\mathrm{Ca}^{2+}\right]_{\mathrm{i}}\right)(2,8)$, suggesting that CaSRs could be involved in the regulation of gastric acid secretion. Indeed, further experiments using freshly isolated rat gastric glands demonstrated that activation of the CaSR leads to a stimulation of histamine-induced $\mathrm{H}^{+}-\mathrm{K}^{+}$-ATPase activity (8). On the other hand, inactivation of CaSRs by a reduction of extracellular divalent cations prevented the histamine-mediated stimulation of $\mathrm{H}^{+}-\mathrm{K}^{+}$-ATPase activity. Taken together, these results suggested that the CaSR represents a novel receptor in the stomach that may modulate the histamine-induced stimulation of gastric acid secretion $(8,10)$.

The investigation of human parietal cells and the regulation of acid secretion has been hampered in the past by the lack of appropriate human cell models as most cell lines lose their responsiveness to physiological stimuli for acid secretion or alter their morphology or the expression of key proteins involved in ion transport and acid secretion (17). The use of freshly isolated human gastric glands may therefore be useful to investigate some aspects of short-term regulation and basic properties of ion transport and acid secretion. Some attempts have been made in the past to use gastric glands obtained from biopsy samples and measure several parameters linked to parietal cell activity (14).

To this end, we tested if fresh tissue samples obtained from stomach surgery could be used to isolate intact human gastric glands and if these glands were viable for physiological experiments. Furthermore, we examined whether a CaSR-dependent

The costs of publication of this article were defrayed in part by the payment of page charges. The article must therefore be hereby marked "advertisement" in accordance with 18 U.S.C. Section 1734 solely to indicate this fact. 
pathway modulating acid secretion via $\mathrm{H}^{+}-\mathrm{K}^{+}$-ATPase is present in human parietal cells. Our results demonstrate that freshly isolated gastric glands are viable and express functional $\mathrm{H}^{+}-\mathrm{K}^{+}$-ATPases stimulated by histamine. Expression of the CaSR was shown by immunohistochemistry, and this receptor modulates $\mathrm{H}^{+}-\mathrm{K}^{+}$-ATPase activity in human parietal cells.

\section{MATERIALS AND METHODS}

Patients. Over a period of $8 \mathrm{mo}$, samples of gastric tissue were obtained from a total of 29 patients. Patients underwent the Roux enY gastric bypass operation for morbid obesity (7), and small samples of gastric tissue (including mucosal and muscle layers) from the gastrojejunal anastomosis were collected. Gastric tissue originated from the fundus of the stomach. Samples were collected from 8 male and 21 female patients. Male patients had an average age of $48.6 \pm 2.6 \mathrm{yr}$ with an average body mass index of $44.4 \pm 2.6$. Female patients were $39.9 \pm$ $2.2 \mathrm{yr}$ old and had a body mass index of $44.3 \pm 1.2$. Because of obesity, many of the patients suffered from metabolic syndrome (31.0\%). Drugs altering gastric acid secretion (proton pump inhibitors, $\mathrm{H}_{2}$ receptor antagonists) were discontinued $1 \mathrm{wk}$ before the surgery.

Informed consent was obtained from all patients, and the study was approved by the local Ethics committee.

Isolation of gastric glands and digital imaging for intracellular $\mathrm{pH}$ and $\mathrm{Ca}^{2+}$. Gastric tissue was stored for transport in ice-cold MEM solution (GIBCO; Langley, OK). Tissue was then transferred to the stage of a dissecting microscope and sliced into $0.5-\mathrm{cm}$ square sections. Individual glands were isolated using a hand dissection technique as described previously $(8,13)$ at a temperature of about $10^{\circ} \mathrm{C}$. After isolation, the glands were transferred to coverslips precoated with adhesive Cell-Tak (BD Cell-Tak Cell and Tissue Adhesion, BD Biosciences) and mounted in a thermostatically controlled chamber maintained at $37^{\circ} \mathrm{C}$ on an inverted microscope (Zeiss Axiovert 200) equipped with an video-imaging system for the duration of the experiment. Isolated gastric glands were loaded with $10 \mu \mathrm{M}$ of the pH-sensitive dye 2',7'-bis-(2-carboxyethyl)-5-(and 6)-carboxyfluorescein (BCECF) AM (Molecular Probes; Eugene, OR) for $10 \mathrm{~min}$ in HEPES-buffered Ringer solution (125 mM NaCl, $5 \mathrm{mM} \mathrm{KCl,} 1 \mathrm{mM}$ $\mathrm{CaCl}_{2}, 1.2 \mathrm{mM} \mathrm{MgCl}, 32.2 \mathrm{mM}$ HEPES, and $5 \mathrm{mM}$ glucose; $\mathrm{pH}$ 7.4) at $37^{\circ} \mathrm{C}$. After the glands were loaded, the chamber was flushed with HEPES-buffered Ringer solution to remove nondeesterfied dye. Measurements were performed in the epifluorescence mode with a $\times 40$ / 1.30 oil-immersion objective on an inverted microscope. BCECF was successively excited at $440 \mathrm{~nm}$ and $495 \mathrm{~nm}$ from a monochromator light source, and the resultant fluorescence signal was monitored at $535 \mathrm{~nm}$ using an intensified charge-coupled device camera. Data points were acquired every $7 \mathrm{~s}$. Resulting 495-to-440-nm intensity ratio data were converted to intracellular $\mathrm{pH}\left(\mathrm{pH}_{\mathrm{i}}\right)$ values using the high- $\mathrm{K}^{+}$/Nigericin calibration technique (19). Over the $\mathrm{pH}$ range of 6.3-7.8, fluorescence varied in a linear fashion with extracellular $\mathrm{pH}$. Data are expressed as changes in $\mathrm{pH}(\Delta \mathrm{pH})$ per minute. Acid extrusion was monitored in the absence of bicarbonate as intracellular alkalinization after the removal of $\mathrm{Na}^{+}$from the bath and using the $\mathrm{NH}_{4} \mathrm{Cl}$ prepulse technique, which caused reproducible and sustained intracellular acidification. Alkalinization rates $\left(\Delta \mathrm{pH}_{\mathrm{i}} / \mathrm{min}\right)$ for the calculation of $\mathrm{Na}^{+}$-independent $\mathrm{pH}_{\mathrm{i}}$ recovery $\left(\mathrm{H}^{+}-\mathrm{K}^{+}\right.$-ATPase activity) and $\mathrm{Na}^{+}$-dependent $\mathrm{pH}_{\mathrm{i}}$ recovery $\left(\mathrm{Na}^{+} / \mathrm{H}^{+}\right.$exchanger activity) rates were measured in ranges of $\mathrm{pH}$ of $6.50-6.70$ and 6.75-6.90, respectively.

To measure $\mathrm{Ca}_{\mathrm{i}}^{2+}$, gastric glands were loaded with $10 \mu \mathrm{M}$ of the $\mathrm{Ca}^{2+}$-sensing dye fura-2 AM (Molecular Probes) in the chamber for $20 \mathrm{~min}$ at room temperature. To eliminate residual nondeesterfied dye from the bath, glands were superfused with standard HEPES-buffered Ringer solution for 2 min. Fura-2 was excited with light of 340/ 380 -nm wavelengths. $\left[\mathrm{Ca}^{2+}\right]_{\mathrm{i}}$ was calculated from the ratio of fluorescence at excitations of $340 / 380 \mathrm{~nm}$ using the following equation as described previously: $\mathrm{Ca}_{\mathrm{i}}^{2+}=\left[\left(\mathrm{R}-\mathrm{R}_{\min }\right) /\left(\mathrm{R}_{\max }-\mathrm{R}\right)\right] \times\left(\mathrm{F}_{\min } /\right.$
$\left.\mathrm{F}_{\max }\right) \times K_{\mathrm{d}}$, where $\mathrm{R}$ is the measured ratio of emitted light, $\mathrm{R}_{\min }$ is, $\mathrm{R}_{\max }$ is, $\mathrm{F}_{\max }$ is the fluorescence at $380 \mathrm{~nm}$ with $2 \mathrm{mM} \mathrm{Ca}^{2+}$ bath solution, $F_{\min }$ is the fluorescence at $380 \mathrm{~nm}$ with $0 \mathrm{mM} \mathrm{Ca}^{2+}$ bath solution, and the dissociation constant $\left(K_{\mathrm{d}}\right)=225 \mathrm{nM}$ for fura-2calcium binding (9).

All chemicals used were obtained from Sigma and Molecular Probes. Omeprazole was a kind gift from Astra Hässle (Mölndal, Sweden).

Activation of acid secretion via histamine and inhibition by omeprazole was induced by preincubation of the glands for 10 min before the experiment combined with BCECF. All data are summarized as means $\pm \mathrm{SE}$ and were analyzed by grouping measurements at baseline values and during experimental periods. Significance was determined using an unpaired Student's $t$-test with $P<0.05$ considered to be statistically significant.

Immunohistochemistry. Human stomach samples were washed several times with PBS and fixed by immersion with paraformaldehydelysine-periodate fixative (16) overnight at $4^{\circ} \mathrm{C}$. Stomachs were washed three times with PBS, and thin sections were cut at a thickness of $5 \mu \mathrm{m}$ after cryoprotection with $2.3 \mathrm{M}$ sucrose in PBS for at least $12 \mathrm{~h}$. Immunostaining was carried out as described previously (13). Sections were incubated with $1 \%$ SDS for $5 \mathrm{~min}$, washed three times with PBS, and incubated with PBS containing 1\% BSA for $15 \mathrm{~min}$ before incubation with the primary antibody. The primary antibodies [mouse monoclonal anti-pig $\beta$-gastric $\mathrm{H}^{+}-\mathrm{K}^{+}$-ATPase (Affinity Bioreagents), rabbit polyclonal anti-pig $\alpha$-gastric $\mathrm{H}^{+}-\mathrm{K}^{+}$-ATPase (Chemicon), rabbit polyclonal affinity-purified anti-CaSR against amino acids 12-27 of rat CaSR (Affinity Bioreagents)] were diluted $1: 2,000,1: 1,000$, and 1:50, respectively, in PBS and applied overnight at $4{ }^{\circ} \mathrm{C}$. In addition, rabbit polyclonal antibody was generated to a maltose-binding fusion protein (MBP) of the entire extracellular domain of the rat CaSR (residues 1-642). The rabbit anti-rat $\mathrm{CaSR}^{1-642}$ polyclonal antibody was affinity purified using the MBPCaSR protein (AminoLink Plus Immobilization Trial Kit, Pierce) and used at a dilution of 1:50. Peptide protection experiments were performed by incubating the affinity-purified antibody at 1:50 with the immunizing peptide $(0.8 \mu \mathrm{g} / \mathrm{ml})$ in PBS for $1 \mathrm{~h}$ at room temperature and directly applying the dilution after centrifugation to remove precipitates. Stomach sections were then washed twice for 5 min with high-NaCl-PBS (PBS $+2.7 \% \mathrm{NaCl}$ ) and once with PBS and incubated with secondary antibodies [donkey anti-rabbit Alexa 546 and donkey anti-mouse Alexa 488 (Molecular Probes)] at a dilution of $1: 1,000$ and 1:200, respectively, for $1 \mathrm{~h}$ at room temperature. Sections were washed twice with high-NaCl-PBS and once with PBS before being mounted with VectaMount (Vector Laboratories; Burlingame, CA). Specimens were viewed with a Leica SP1 UV CLSM confocal microscope, and pictures were processed using Adobe Photoshop.

\section{RESULTS}

Freshly isolated human gastric glands are suitable for functional experiments. In the first series of experiments, we tested whether the freshly isolated human gastric glands were suitable for functional experiments investigating regulation of $\mathrm{H}^{+}-\mathrm{H}^{+}$-ATPase activity. To this end, immunohistochemistry was performed on the tissue samples obtained to examine expression of both subunits of gastric $\mathrm{H}^{+}-\mathrm{K}^{+}$-ATPase. Immunohistochemistry demonstrated that both $\alpha$ - and $\beta$-subunits could be detected, and thus acid-secretory parietal cells were present in samples obtained from the antral part of the human stomach (Fig. 1). $\mathrm{pH}_{\mathrm{i}}$ measurements of single parietal cells within freshly isolated gastric glands were used to measure $\mathrm{H}^{+}-\mathrm{K}^{+}$-ATPase activity. The activity of the pump was calculated from the rate of alkalinization of $\mathrm{pH}_{\mathrm{i}}\left(\Delta \mathrm{pH}_{\mathrm{i}} / \mathrm{min}\right)$ after acidification using the $\mathrm{NH}_{4} \mathrm{Cl}$ prepulse technique in the absence of sodium and bicarbonate. $\mathrm{H}^{+}$extrusion under these 

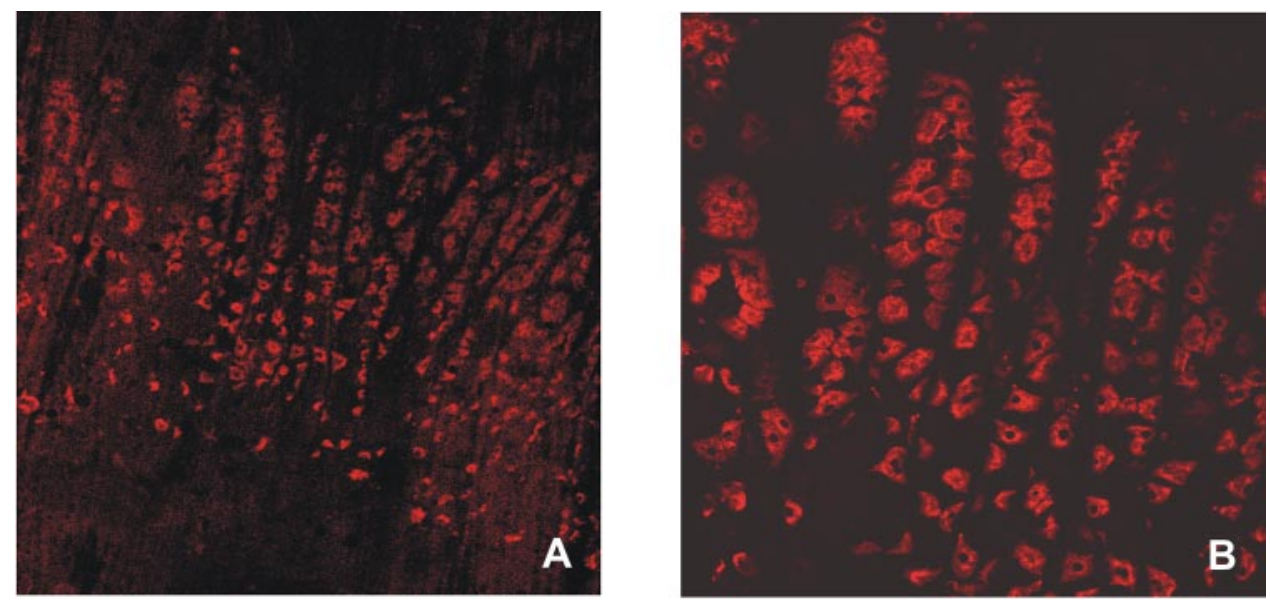

Fig. 1. Immunolocalization of $\alpha$ - and $\beta$-subunits of gastric $\mathrm{H}^{+}-\mathrm{K}^{+}$-ATPase in the human stomach. Samples of the human stomach obtained from the antral part were stained with specific antibodies against the $\alpha$-subunit $(A$ and $B$ ) and $\beta$-subunit $(C)$ of gastric $\mathrm{H}^{+}-\mathrm{K}^{+}$-ATPase. The distribution and localization was specific only to a subset of cells in the neck region of the glands resembling parietal cells, as described previously (15). $D$ : high magnification shows localization of the $\mathrm{H}^{+}-\mathrm{K}^{+}$-ATPase $\beta$-subunit in tubular intracellular compartments, consistent with the described localization of $\mathrm{H}^{+}-\mathrm{K}^{+}$ATPase in tubulovesicular structures. Magnification: $\times 200$ in $A-C$ and $\times 800$ in $D$.
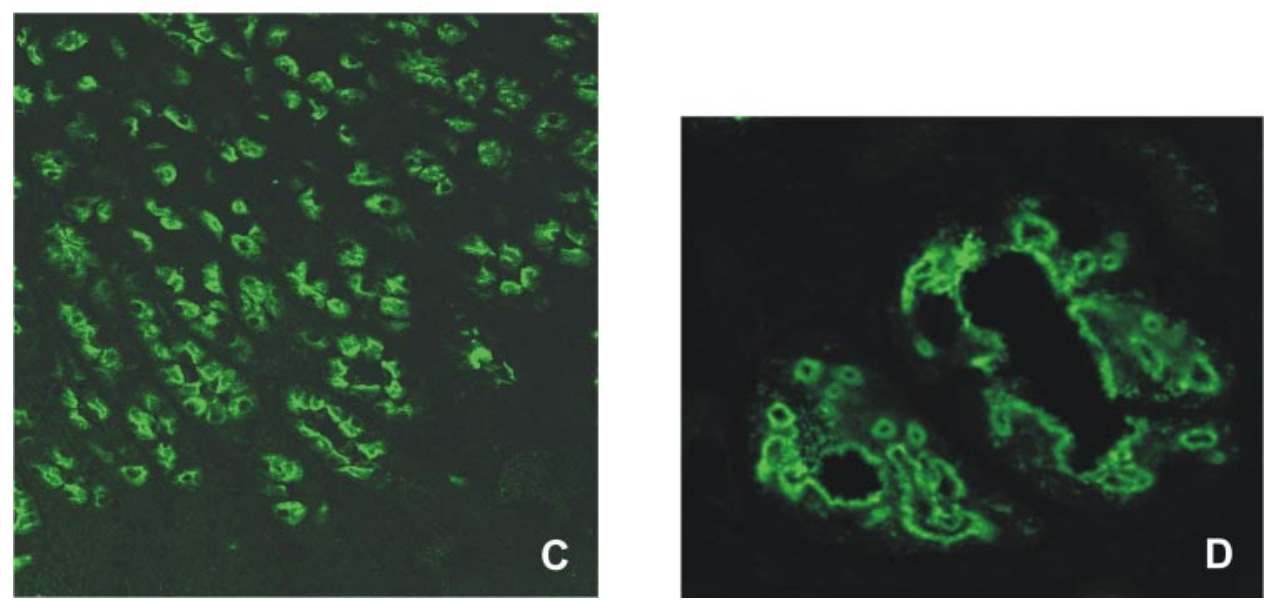

conditions depends mainly on activity of $\mathrm{H}^{+}-\mathrm{K}^{+}$-ATPase, as previously shown (8). In the absence of any stimulation (i.e., histamine or acetylcholine), only a low rate of $\mathrm{pH}_{\mathrm{i}}$ recovery was observed $(0.010 \pm 0.004 \mathrm{pH}$ units $/ \mathrm{min}, n=60$ parietal cells from 4 glands from 4 patients; Fig. 2, $A$ and $D$ ). After exposure of the glands to histamine $(100 \mu \mathrm{M})$, the rate of $\mathrm{Na}^{+}$-independent $\mathrm{pH}_{\mathrm{i}}$ alkalinization increased to $0.024 \pm$ $0.003 \mathrm{pH}$ units $/ \mathrm{min}(n=50$ parietal cells from 5 glands from 2 patients; Fig. 2, $B$ and $D$ ). To confirm that this stimulation of the $\mathrm{Na}^{+}$-independent $\mathrm{pH}_{\mathrm{i}}$ recovery represented $\mathrm{H}^{+}-\mathrm{K}^{+}$ATPase activity, glands were preincubated with $100 \mu \mathrm{M}$ of the specific inhibitor of gastric $\mathrm{H}^{+}-\mathrm{K}^{+}$-ATPase omeprazole for 10 min before experiments in the presence of histamine $(100 \mu \mathrm{M})$. Omeprazole prevented the stimulatory effect of histamine on the $\mathrm{Na}^{+}$-independent $\mathrm{pH}_{\mathrm{i}}$ recovery rate $(0.0094 \pm 0.002 \mathrm{pH}$ units/min) and reduced it to the same level as seen in glands not exposed to histamine $(n=65$ parietal cells from 3 glands from 4 patients; Fig. 2, $C$ and $D$ ). Thus the freshly isolated human gastric glands contained functional parietal cells that showed $\mathrm{H}^{+}-\mathrm{K}^{+}$-ATPase activity that could be stimulated with the physiological agonist histamine and inhibited by the specific blocker omeprazole.

Expression of the CaSR in human parietal cells. Immunohistochemistry using two different antibodies directed against different epitopes of the CaSR demonstrated staining of the basolateral side of a subset of cells along the gastric gland (Fig.
$3 A)$. No specific signal for CaSR was observed with preimmune serum (Fig. $3 F$ ), after peptide protection with the immunizing peptide (Fig. $3 G$ ), or with application of only the secondary antibody (Fig. $3 H$ ). To test whether the CaSR was expressed in parietal cells, double labeling for the CaSR and the $\beta$-subunit of gastric $\mathrm{H}^{+}-\mathrm{K}^{+}$-ATPase was performed in samples obtained from patients that fasted for at least $12 \mathrm{~h}$ before the operation. Colocalization of both the CaSR and the $\beta$-subunit of gastric $\mathrm{H}^{+}-\mathrm{K}^{+}$-ATPase was observed, demonstrating expression of the CaSR in human gastric parietal cells (Fig. 3). Higher magnification pictures showed that the CaSR and the $\mathrm{H}^{+}-\mathrm{K}^{+}$-ATPase $\beta$-subunit do not localize to the same compartment of resting parietal cells, with the $\mathrm{H}^{+}-\mathrm{K}^{+}$-ATPase $\beta$-subunit residing in intracellular structures, consistent with its localization in tubulovesicular structures (Fig. 3, $D$ and $E$ ).

Modulation of histamine-induced stimulation of $\mathrm{H}^{+}-\mathrm{K}^{+}$ATPase activity by CaSR in human gastric glands. To examine the effect of the CaSR on the activity of gastric $\mathrm{H}^{+}-\mathrm{K}^{+}$ATPase and its stimulation by histamine, we reduced the concentration of total divalent cations from $1 \mathrm{mM} \mathrm{Mg}^{2+}$ and $1.2 \mathrm{mM} \mathrm{Ca}^{2+}$ in control solution to only $0.1 \mathrm{mM} \mathrm{Ca}^{2+}$ and 0 $\mathrm{mM} \mathrm{Mg}{ }^{2+}$, a concentration of divalent cations leaving the CaSR inactive. Glands were preincubated in this low-divalent cation solution for $10 \mathrm{~min}$ before the experiment and were stimulated with $100 \mu \mathrm{M}$ histamine as described above. Conditions of low extracellular divalent cations abolished hista- 

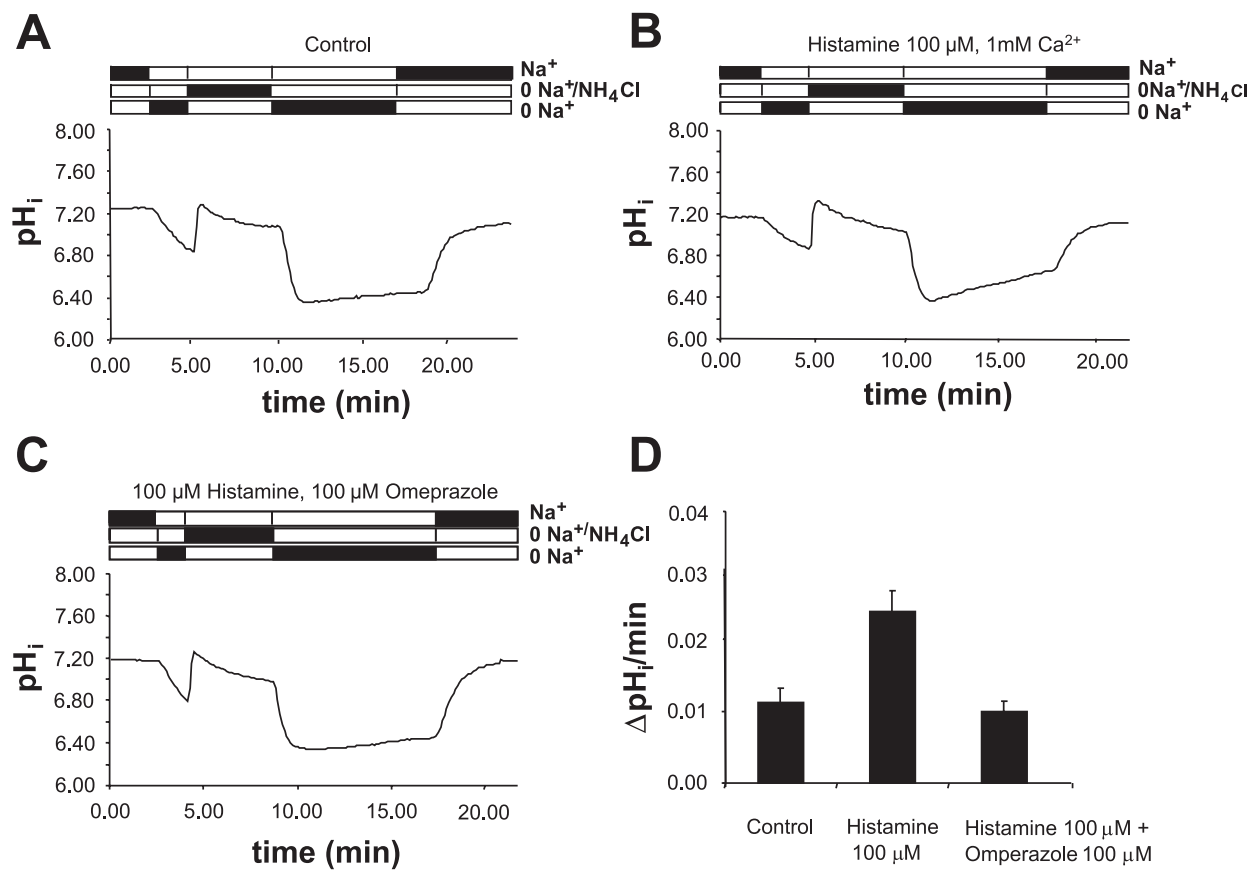

D
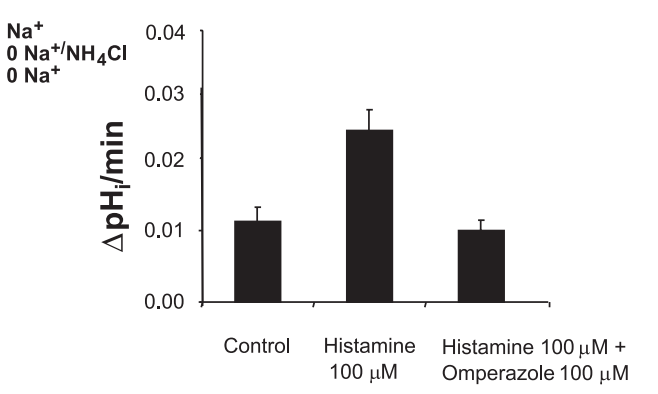

Fig. 2. $\mathrm{H}^{+}-\mathrm{K}^{+}$-ATPase activity measurements in freshly isolated human gastric glands. Single human gastric glands were prepared and loaded with the $\mathrm{pH}$-sensitive dye 2',7'-bis-(2-carboxyethyl)-5-(and 6)-carboxyfluorescein, and intracellular $\mathrm{pH}\left(\mathrm{pH}_{\mathrm{i}}\right)$ was measured in single parietal cells. $\mathrm{H}^{+}-\mathrm{K}^{+}$-ATPase was calculated from the omeprazole $(\mathrm{Omp})$-sensitive $\mathrm{pH}_{\mathrm{i}}$ recovery rate after an acid load using the $\mathrm{NH}_{4} \mathrm{Cl}$ prepulse. A: original $\mathrm{pH}_{\mathrm{i}}$ tracing of a control gland. $B$ : stimulation of $\mathrm{pH}_{\mathrm{i}}$ recovery by incubation of the glands with histamine (Hist; $100 \mu \mathrm{M}) . C$ : inhibition of histamine-stimulated $\mathrm{pH}_{\mathrm{i}}$ recovery by the $\mathrm{H}^{+}-\mathrm{K}^{+}$-ATPase inhibitor omeprazole $(100 \mu \mathrm{M})$ demonstrates that histamine-stimulated $\mathrm{pH}_{\mathrm{i}}$ recovery is mediated by gastric $\mathrm{H}^{+}-\mathrm{K}^{+}$-ATPase. $D$ : bar graph summarizing data as means $\pm \mathrm{SE}$ (control: $n=$ 60 cells from 4 glands from 4 patients; histamine: $n=50$ cells from 5 glands from 2 patients; histamine + omeprazole: $n=65$ cells from 3 glands from 4 patients). mine-induced alkalinization $(0.015 \pm 0.003 \mathrm{pH}$ units $/ \mathrm{min}, n=$ 61 parietal cells from 9 glands from 9 patients; Fig. 4C). In contrast, stimulation of the CaSR with the trivalent cation $\mathrm{Gd}^{3+}(100 \mu \mathrm{M})$ in low-divalent cation solution $\left(100 \mu \mathrm{M} \mathrm{Ca}^{2+}\right.$, $0 \mathrm{mM} \mathrm{Mg}^{2+}$ ) stimulated $\mathrm{H}^{+}-\mathrm{K}^{+}$-ATPase activity even in the absence of histamine $\left(\mathrm{Na}^{+}\right.$-independent $\mathrm{pH}_{\mathrm{i}}$ recovery: $0.075 \pm$ $0.004 \mathrm{pH}$ units $/ \mathrm{min}, n=68$ parietal cells from 8 glands from 6 patients; Fig. 4B). This stimulatory effect was also seen when gastric glands were preincubated with histamine in low-divalent cation solution $\left(100 \mu \mathrm{M} \mathrm{Ca}^{2+}, 0 \mathrm{mM} \mathrm{Mg}{ }^{2+}\right)$ and $\mathrm{Gd}^{3+}$ applied directly during the phase of $\mathrm{Na}^{+}$-independent alkalinization. $\mathrm{Gd}^{3+}$ induced an immediate increase in the alkalinization rate (data not shown), suggesting a rapid activation of $\mathrm{H}^{+}$ extrusion. Similarly, increasing extracellular $\mathrm{Ca}^{2+}$ to $5 \mathrm{mM}$ in the presence of histamine stimulated $\mathrm{H}^{+}-\mathrm{K}^{+}$-ATPase activity above levels seen at $1 \mathrm{mM}$ extracellular $\mathrm{Ca}^{2+}(n=101$ parietal cells from 6 glands from 4 patients). These data suggest that also the physiological ligand $\mathrm{Ca}^{2+}$ can stimulate the CaSR and increase $\mathrm{H}^{+}-\mathrm{K}^{+}$-ATPase activity.

To rule out that histamine released from neighbouring ECL cells mediated the effect of $\mathrm{Gd}^{3+}$ on parietal cells, gastric glands were preincubated with the $\mathrm{H}_{2}$ receptor inhibitor cimetidine $(100 \mu \mathrm{M})$ and stimulated with $\mathrm{Gd}^{3+}$. The $\mathrm{Na}^{+}$-independent $\mathrm{pH}_{\mathrm{i}}$ recovery rate was not altered by incubation with cimetidine, and $\mathrm{Gd}^{3+}$ was still effective in stimulating realkalinization $(0.095 \pm 0.01 \mathrm{pH}$ units $/ \mathrm{min}, n=34$ parietal cells from 4 glands from 2 patients; Fig. 5).

Furthermore, to examine if $\mathrm{Gd}^{3+}$-induced stimulation of the $\mathrm{Na}^{+}$-independent $\mathrm{pH}_{\mathrm{i}}$ recovery rate was due $\mathrm{H}^{+}-\mathrm{K}^{+}$-ATPase activity, gastric glands were preincubated for $10 \mathrm{~min}$ with the $\mathrm{H}^{+}-\mathrm{K}^{+}$-ATPase inhibitor omeprazole $(100 \mu \mathrm{M})$, which almost completely abolished intracellular alkalinization $(0.011 \pm$ $0.001 \mathrm{pH}$ units/min, $n=58$ parietal cells from 6 glands from 4 patients; Fig. 5), demonstrating that the CaSR stimulated $\mathrm{H}^{+}-\mathrm{K}^{+}$-ATPase activity.

CaSR activation leads to increases in $\mathrm{Ca}_{\mathrm{i}}^{2+}$. CaSR activation has been shown to induce increases in $\left[\mathrm{Ca}^{2+}\right]_{i}$ in rat gastric parietal cells and in a number of other tissue preprations and cell culture lines $(2,3,8)$. Therefore, we tested whether activation of CaSR by $\mathrm{Gd}^{3+}$ increased $\mathrm{Ca}_{i}^{2+}$. Activation of the CaSR with $\mathrm{Gd}^{3+}(100 \mu \mathrm{M})$ increased $\mathrm{Ca}_{i}^{2+}$ even under conditions of low extracellular divalent cations (Fig. 6).

\section{DISCUSSION}

Gastric acid secretion involves a complex process of either neuronal or paracrine stimulatory pathways converging in the insertion of $\mathrm{H}^{+}-\mathrm{K}^{+}$-ATPases into the luminal membrane of acid-secretory parietal cells (for a review, see Ref. 20). Besides the classic routes of activation through acetyl choline, gastrin, and histamine, a number of metabolic factors (including serum calcium and protein) or amino acid-rich diets influence gastric acid secretion via only partly characterized pathways. The recent identification of the CaSR in gastric tissue and its localization to parietal cells has raised the question as to its function in these specialized cells and its potential role as a metabolic sensor $(10)$. We $(2,8)$ have previously shown that the CaSR is functionally active in rat parietal cells and is able to modulate gastric acid secretion via stimulation of $\mathrm{H}^{+}-\mathrm{K}^{+}$ATPase activity. In the present study, we tested whether freshly isolated human gastric glands could be used for functional studies using a modification of the techniques that we had previously developed for rat and mouse isolated gastric glands. Our results demonstrate that freshly isolated human glands expressed both subunits of gastric $\mathrm{H}^{+}-\mathrm{K}^{+}$-ATPase and secrete acid in response to histamine and that acid secretion is sensitive to the specific inhibitor omeprazole.

We also demonstrated that the CaSR is expressed in human gastric parietal cells and is functionally active. Stimulation of the CaSR by increased concentrations of divalent or trivalent ions led to enhanced proton extrusion via omeprazole-sensitive $\mathrm{H}^{+}-\mathrm{K}^{+}$-ATPase. A reduction of extracellular divalent cations resulted in a reduction, or, in the case of histamine, an inactivation, of histamine-induced $\mathrm{H}^{+}-\mathrm{K}^{+}$-ATPase activity. Thus enhanced CaSR activity can modulate $\mathrm{H}^{+}-\mathrm{K}^{+}$-ATPase activity 

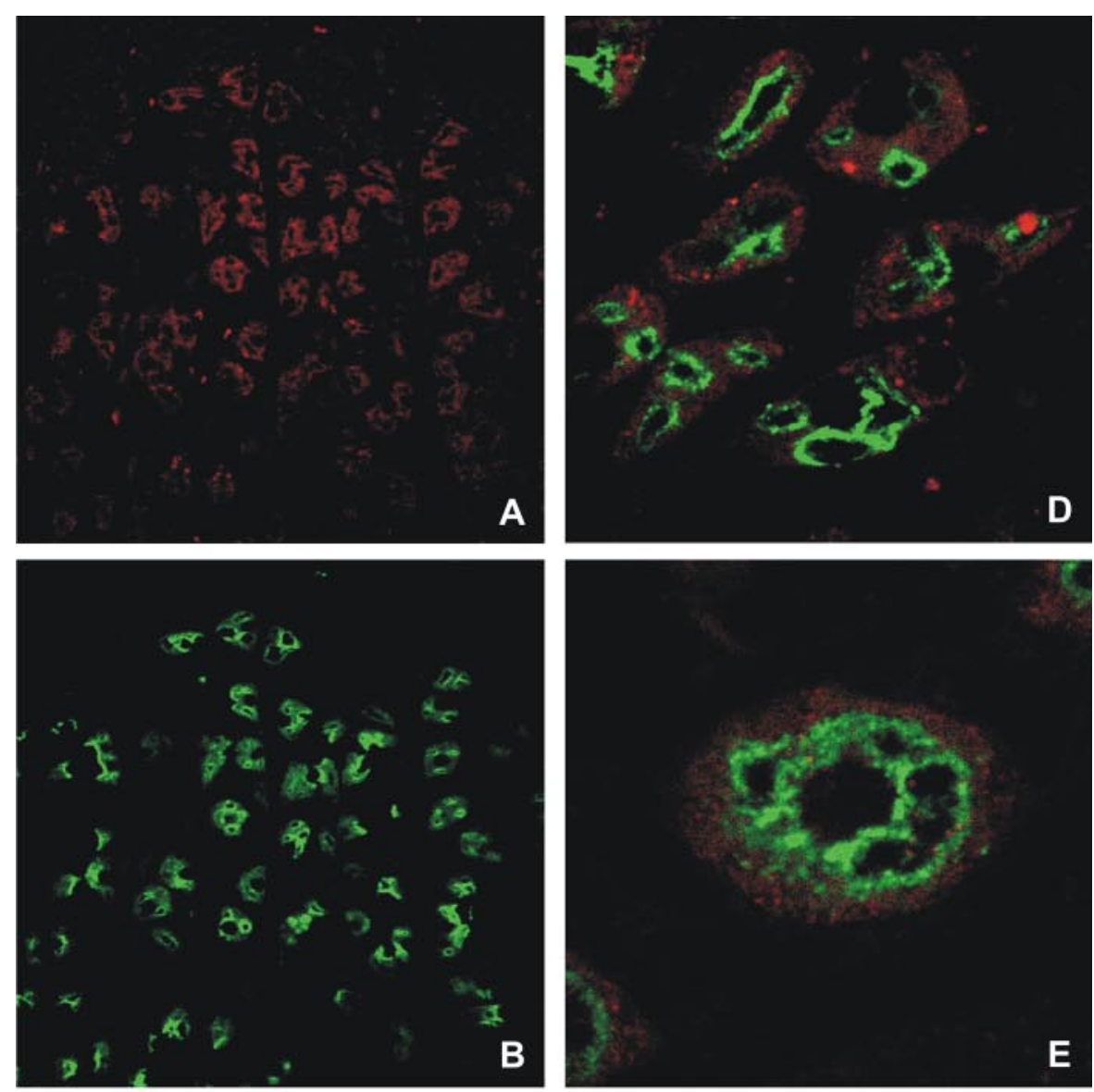

Fig. 3. Localization of the calcium-sensing receptor (CaSR) in the human stomach. Human stomach samples obtained from fasted patients were used to localize the CaSR. A: staining of a subset of cells was observed with an antiserum raised against CaSR (red). $B$ : staining against the $\mathrm{H}^{+}-\mathrm{K}^{+}$-ATPase $\beta$-subunit to identify acid-secreting parietal cells (green). $C$ : overlay of stainings against CaSR (red) and the $\mathrm{H}^{+}-\mathrm{K}^{+}$-ATPase $\beta$-subunit (green) demonstrates expression of both proteins in the same cells. $D$ and $E$ : high-magnification pictures showing that the CaSR (red) is localized to a different subcellular compartment than the $\mathrm{H}^{+}-\mathrm{K}^{+}$-ATPase $\beta$-subunit (green) in resting parietal cells. $F-H$ : overlay of stainings against the $\mathrm{H}^{+}-\mathrm{K}^{+}$-ATPase $\beta$-subunit (green) and with the use of preimmune serum against the CaSR $(F)$, preincubation of anti-CaSR with the immunizing peptide $(G)$, or omission of the anti-CaSR antibody (all in red) and use of only the secondary antibody $(H)$, which demonstrate that no signal similar to the CaSR could be seen. Magnification: $\times 400$ in $A-C$ and $F-H, \times 600$ in $D$, and $\times 800$ in $E$.
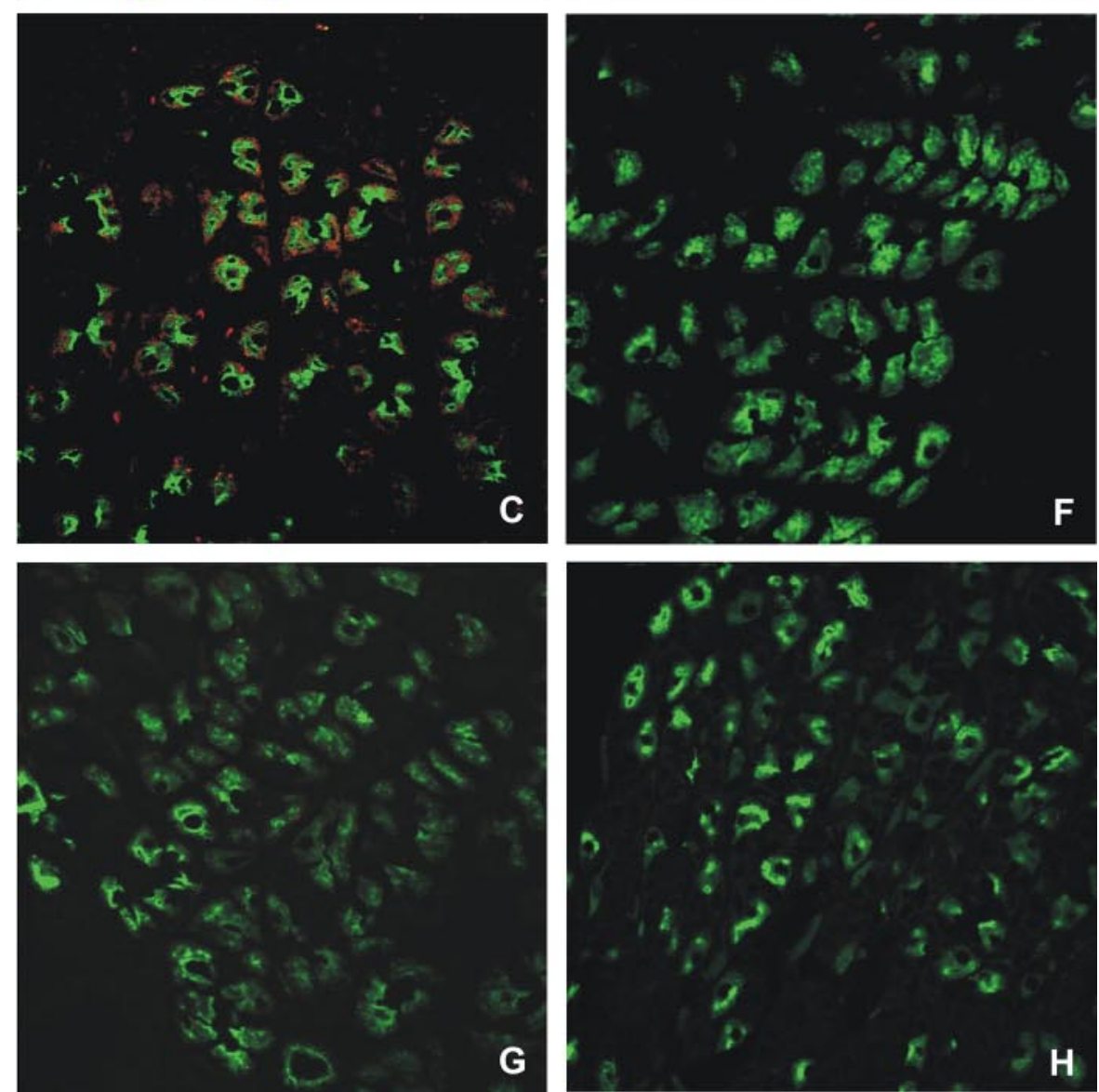
Histamine $100 \mu \mathrm{M}, 100 \mu \mathrm{M} \mathrm{Ca}^{2+}, 0 \mathrm{Mg}^{2+}$

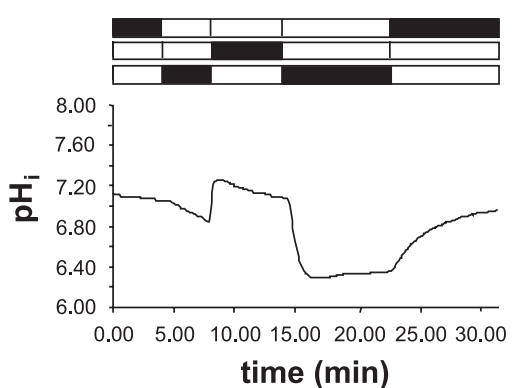

time (min)

C

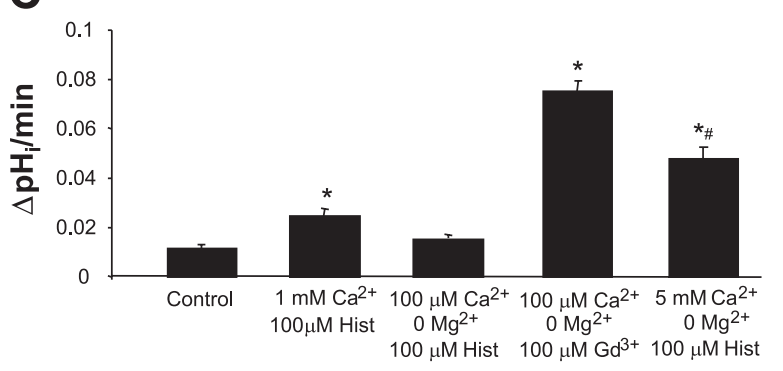

Fig. 4. Acid secretion is modulated by the CaSR. A: reduction of extracellular cations from $1 \mathrm{mM} \mathrm{Ca}^{2+}$ and $1.2 \mathrm{mM} \mathrm{Mg}^{2+}$ to 100

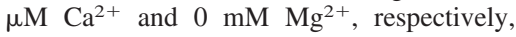
abolished the stimulatory effect of histamine on intracellular alkalinization $\left(\mathrm{H}^{+}-\mathrm{K}^{+}\right.$ATPase activity) ( $n=61$ cells from 9 glands from 9 patients). $B$ : addition of the divalent cation receptor agonist $\mathrm{Gd}^{3+}(100 \mu \mathrm{M})$ even in a low cation-containing solution induced an increase of the rate of alkalinization in both the presence or absence of histamine $(n=68$ cells from 8 glands from 6 patients). $C$ : bar graph summarizing the effects of low and high divalent cations and $\mathrm{Gd}^{3+}$ on $\mathrm{H}^{+}-\mathrm{K}^{+}$ATPase activity. *Significant difference between experimental treatments and control; \#significant difference between $1 \mathrm{mM} \mathrm{Ca}^{2+}+$ $100 \mu \mathrm{M}$ histamine and $5 \mathrm{mM} \mathrm{Ca}^{2+}+100$ $\mu \mathrm{M}$ histamine.

in both the absence and presence of the potent secretagogue histamine. However, it remains to be established whether the CaSR provides a pathway for stimulation or regulation of gastric acid secretion independent from the classic route via histamine or acetylcholine in vivo. Activation of the CaSR was associated with a rise in $\mathrm{Ca}_{\mathrm{i}}^{2+}$, an event that has been linked to activation of $\mathrm{H}^{+}-\mathrm{K}^{+}$-ATPases. A direct correlation in $\mathrm{Ca}_{\mathrm{i}}^{2+}$ levels and CaSR-mediated regulation of $\mathrm{H}^{+}-\mathrm{K}^{+}$-ATPase activity requires further investigation.

The CaSR has also been shown to be sensitive to changes in extracellular $\mathrm{pH}$ and to be allosterically sensitized by L-amino acids shifting the activation curve for divalent cations to the left $(5,6,18)$. Both high extracellular $\mathrm{Ca}^{2+}$ and L-amino acids have been shown to stimulate gastric acid secretion through only poorly understood mechanisms. We have recently shown that $\mathrm{L}$-amino acids can stimulate gastric $\mathrm{H}^{+}-\mathrm{K}^{+}$-ATPase activ-

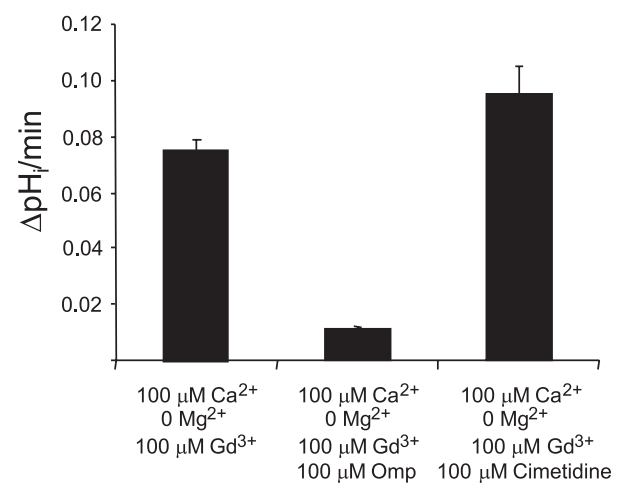

Fig. 5. CaSR stimulates $\mathrm{H}^{+}-\mathrm{K}^{+}$-ATPase activity and does not require $\mathrm{H}_{2}$ receptors. Inhibition of $\mathrm{H}^{+}-\mathrm{K}^{+}$-ATPase activity with the specific inhibitor omeprazole $(100 \mu \mathrm{M})$ abolished the stimulatory effect of $\mathrm{Gd}^{3+}$ on the rate of $\mathrm{pH}_{\mathrm{i}}$ recovery, demonstrating that $\mathrm{Gd}^{3+} / \mathrm{CaSR}$ activates $\mathrm{H}^{+}$extrusion via $\mathrm{H}^{+}-\mathrm{K}^{+}$-ATPase ( $n=58$ cells from 6 glands from 4 patients). Blockade of $\mathrm{H}_{2}$ histamine receptors with cimetidine $(100 \mu \mathrm{M})$ did not influence the $\mathrm{Gd}^{3+}$. stimulated $\mathrm{pH}$ recovery, ruling out the involvement of histamine in the effect on $\mathrm{H}^{+}-\mathrm{K}^{+}$-ATPase activity $(n=34$ cells from 4 glands from 2 patients).
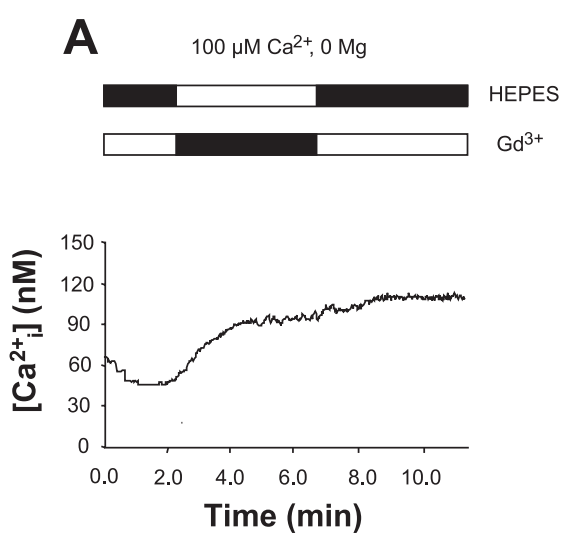

B

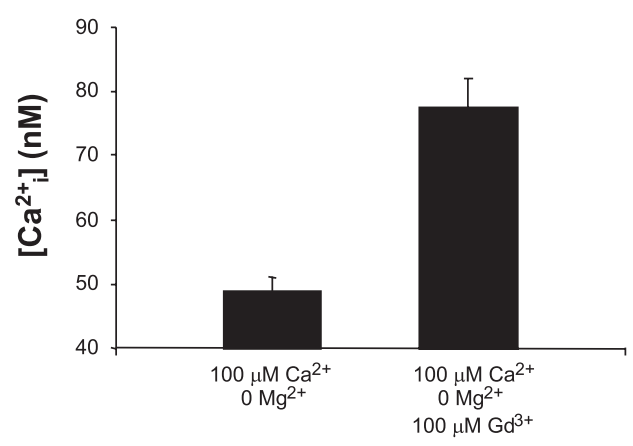

Fig. 6. Activation of the $\mathrm{CaSR}$ by $\mathrm{Gd}^{3+}$ increases the intracellular calcium concentration $\left(\left[\mathrm{Ca}^{2+}\right]_{\mathrm{i}}\right)$. A: Original tracing of $\left[\mathrm{Ca}^{2+}\right]_{\mathrm{i}}$ measurements using fura-2 in a single parietal cell, showing that exposure to $\mathrm{Gd}^{3+}(100 \mu \mathrm{M})$ led to a sustained increase in $\left[\mathrm{Ca}^{2+}\right]_{\mathrm{i}}$. $B$ : bar graph summarizing $\left[\mathrm{Ca}^{2+}\right]_{\mathrm{i}}$ measurements in the absence $\left(48.8 \pm 2.3 \mathrm{nM}\right.$ intracellular $\left.\mathrm{Ca}^{2+}\right)$ and presence $(77.6 \pm$ $4.4 \mathrm{nM}$ intracellular $\left.\mathrm{Ca}^{2+}\right)$ of $\mathrm{Gd}^{3+}(n=27$ cells from 3 glands from 2 patients). 
ity in isolated rat gastric glands by a dual mechanism $(1,12)$. At low concentrations, this appears to involve the uptake of amino acids by amino acid transporters, whereas at higher concentrations, the CaSR appears to be involved $(1,12)$. Thus, under these conditions, the CaSR could be acting as a metabolic sensor through which several metabolic pathways could modulate gastric acid secretion (11).

In conclusion, our data show the viability of freshly isolated human gastric glands for investigation of human gastric acid secretion, the identification of the CaSR in parietal cells, and the ability of the CaSR to directly modulate acid secretion independently from secretagogues.

\section{ACKNOWLEDGMENTS}

We thank Dr. Kjell Andersson (AstraZeneca) for providing us with omeprazole.

\section{GRANTS}

This study was supported by a grant from the Hartmann Müller Foundation Zurich (to P. Kirchhoff) and National Institute of Diabetes and Digestive and Kidney Diseases Grants DK-50230, DK-17433, and DK-60069 (to J. P. Geibel).

\section{REFERENCES}

1. Busque SM, Kerstetter JE, Geibel JP, and Insogna K. L-Type amino acids stimulate gastric acid secretion by activation of the calcium-sensing receptor in parietal cells. Am J Physiol Gastrointest Liver Physiol 289: G664-G669, 2005.

2. Cheng I, Qureshi I, Chattopadhyay N, Qureshi A, Butters RR, Hall AE, Cima RR, Rogers KV, Hebert SC, Geibel JP, Brown EM, and Soybel DI. Expression of an extracellular calcium-sensing receptor in rat stomach. Gastroenterology 116: 118-126, 1999.

3. Cheng SX, Geibel JP, and Hebert SC. Extracellular polyamines regulate fluid secretion in rat colonic crypts via the extracellular calcium-sensing receptor. Gastroenterology 126: 148-158, 2003.

4. Chew CS. Cholecystokinin, carbachol, gastrin, histamine, and forskolin increase $\left[\mathrm{Ca}^{2+}\right]_{\mathrm{i}}$ in gastric glands. Am J Physiol Gastrointest Liver Physiol 250: G814-G823, 1986.

5. Conigrave AD, Franks AH, Brown EM, and Quinn SJ. L-Amino acid sensing by the calcium-sensing receptor: a general mechanism for cou- pling protein and calcium metabolism? Eur J Clin Nutr 56: 1072-1080, 2002.

6. Conigrave AD, Quinn SJ, and Brown EM. L-Amino acid sensing by the extracellular $\mathrm{Ca}^{2+}$-sensing receptor. Proc Natl Acad Sci USA 97: 48144819, 2000.

7. Fisher BL and Schauer P. Medical and surgical options in the treatment of severe obesity. Am J Surg 184: 9S-16S, 2002.

8. Geibel JP, Wagner CA, Caroppo R, Qureshi I, Gloeckner J, Manuelidis $\mathbf{L}$, Kirchhoff $\mathbf{P}$, and Radebold $\mathbf{K}$. The stomach divalent ion-sensing receptor scar is a modulator of gastric acid secretion. J Biol Chem 276: 39549-39552, 2001.

9. Grynkiewicz G, Poenie M, and Tsien RY. A new generation of $\mathrm{Ca}^{2+}$ indicators with greatly improved fluorescence properties. J Biol Chem 260: 3440-3450, 1985.

10. Hebert SC, Cheng S, and Geibel J. Functions and roles of the extracellular $\mathrm{Ca}^{2+}$-sensing receptor in the gastrointestinal tract. Cell Calcium 35: 239-247, 2004.

11. Hofer AM and Brown EM. Extracellular calcium sensing and signalling. Nat Rev Mol Cell Biol 4: 530-538, 2003.

12. Kirchhoff P, Dave MH, Remy C, Kosiek O, Busque SM, Dufner M, Geibel JP, Verrey F, and Wagner CA. An amino acid transporter involved in gastric acid secretion. Pflügers Arch. In press.

13. Kirchhoff P, Wagner CA, Gaetzschmann F, Radebold K, and Geibel JP. Demonstration of a functional apical sodium hydrogen exchanger in isolated rat gastric glands. Am J Physiol Gastrointest Liver Physiol 285: G1242-G1248, 2003.

14. Kocsis I, Vasarhelyi B, Tulassay Z, Szabo T, Ver A, and Tulassay T. Determination of $\mathrm{H}^{+} / \mathrm{K}^{+}$-ATPase activity in human gastric biopsy specimens. Clin Chem 38: 743-745, 2000.

15. Kraut JA, Helander KG, Helander HF, Iroezi ND, Marcus EA, and Sachs G. Detection and localization of $\mathrm{H}^{+}-\mathrm{K}^{+}$-ATPase isoforms in human kidney. Am J Physiol Renal Physiol 281: F763-F768, 2001.

16. McLean IW and Nakane PK. Periodate-lysine-paraformaldehyde fixative. A new fixation for immunoelectron microscopy. J Histochem Cytochem 22: 1077-1083, 1974.

17. Okamoto CT and Forte JG. Vesicular trafficking machinery, the actin cytoskeleton, and $\mathrm{H}^{+}-\mathrm{K}^{+}$-ATPase recycling in the gastric parietal cell. J Physiol 532: 287-296, 2001.

18. Quinn SJ, Bai M, and Brown EM. pH sensing by the calcium-sensing receptor. J Biol Chem 279: 37241-37249, 2004.

19. Thomas JA, Buchsbaum RN, Zimniak A, and Racker E. Intracellular $\mathrm{pH}$ measurements in Ehrlich ascites tumor cells utilizing spectroscopic probes generated in situ. Biochemistry 18: 2210-2218, 1979.

20. Yao $\mathbf{X}$ and Forte JG. Cell biology of acid secretion by the parietal cell. Aпnи Rev Physiol 65: 103-131, 2003. 


\section{DANKSAGUNG}

An dieser Stelle möchte ich allen, die mir das Arbeiten im Rahmen meiner Publikation ermöglichten und erleichterten, danken und sie namentlich erwähnen:

- Prof. Dr. Carsten A. Wagner für seine ständige fachliche und emotionale Begleitung und Unterstützung

- Dr. med. Philipp Kirchhoff und Dr. med. Christian Winter für die Begleitung, Einführung und Anleitung sowie emotionale Unterstützung durch die ganze Versuchsreihe hinweg

- Dr. med. Markus K. Müller für die Bereitstellung der benötigten Parietalzellen

- Dem ganzen Team von Prof. Dr. Carsten A. Wagner wie cand. med. Patricia Hafner, Dr. med. Christine Remy, u.v.a..

- Der Hartmann Müller Foundation für die finanzielle Unterstützung

- Dr. Kjell Andersson AstraZeneca, Schweden für die Bereitstellung des für die Studien benötigten Omeprazols

- Sam X. Cheng, Lie-Qi Tang, Steven C. Hebert, John P. Geibel für die Unterstützung aus den USA

- Meiner Familie, ganz besonders meinen Eltern, für die finanzielle Unterstützung und seelische Begleitung während meines ganzen Studiums, was mir diese Promotion erst ermöglichte 


\section{Curriculum vitae}

Matthias Michael Dufner aus Offenburg, Deutschland

1977

1984-1986

1986-1989

1989-1998

2000

2002

2003

2003

$2004 / 05$

$2004 / 05$

2006

2007

2007

2007

Seit 2007
Geboren in Offenburg

Freie Walddorfschule Offenburg

Anne-Frank Grundschule Offenburg

Schiller-Gymnasium Offenburg,

Abitur (2,2)

Beginn des Medizinstudiums an der Universität in Heidelberg

Erfolgreicher Abschluss des Physikums an der Universität in Heidelberg

Erfolgreicher Abschluss des 1. Staatsexamens an der Universität in Heidelberg

Famulatur in der Unfall- und Handchirurgie bei Herrn Professor Rudigier, Kliniken der Ortenau

Publikation zur Vorbereitung meiner Dissertation am Universitätsspital Zürich Abteilung Viszeralchirurgie in Kooperation mit dem Institut für Physiologie der Universität Zürich und Mitarbeit an weiteren Forschungsprojekten

Studium an der Universität Zürich im Rahmen eines Erasmus Stipendiums

Erfolgreicher Abschluss des 2. Staatsexamens an der Universität in Heidelberg

Beginn des praktischen Jahres als Student der Universität Heidelberg

1. Tetrial: Kantonsspital Luzern/ Schweiz,

Abteilung Innere Medizin

2. Tertial: Stadtklinik Baden-Baden/ Deutschland, Abteilung Chirurgie

3.Tertial: Schulthess Klinik Zürich/ Schweiz, Abteilung Orthopädie

Erfolgreicher Abschluss des 3. Staatsexamens am 13.06.2007 an der Universität Heidelberg

Approbation seit Juli 2007

Assistenzarzt der Klinik für diagnostische und interventionelle Radiologie der St. Vincentius-Kliniken Karlsruhe 